\title{
PENGARUH PENERAPAN MODEL PEMBELAJARAN MODEL TWO STAY TWO STRAY (TSTS) TERHADAP PENINGKATAN KEAKTIFAN DAN HASIL BELAJAR SOSIOLOGI DI SMA PASUNDAN 3 BANDUNG
}

\author{
Riestiani Kadiriandi, Yadi Ruyadi \\ Universitas Pendidikan Indonesia \\ Jl. Dr.Setiabudi 229 Bandung 40154, Jawa Barat, Indonesia \\ Email: riestianikadiriandi@gmail.com
}

\begin{abstract}
Abstrak Penelitian ini dilatarbelakangi oleh rendahnya hasil belajar dan keaktifan belajar siswa pada mata pelajaran Sosiologi yang ditandai dengan kurangnya kegiatan siswa dalam proses pembelajaran. Tujuan penelitian ini adalah untuk mengetahui pengaruh model pembelajaran two stay two stray terhadap peningkatan hasil belajar dan keaktifan belajar siswa. Penelitian ini menggunakan pendekatan kuantitatif dengan desain penelitian kuasi eksperimen. Populasi penelitian ini adalah siswa IPS SMA Pasundan 3 Bandung tahun ajaran 2016/2017. Sampel penelitian ini yaitu kelas X IPS 1 sebagai kelas kontrol, X IPS 2 sebagai kelas eksperimen 1, dan kelas X IPS 3 sebagai kelas eksperimen 2. Teknik pengumpulan data dengan menggunakan tes, observasi, dan dokumentasi. Teknis analisis data dengan cara perbandingan hasil belajar dan hasil observasi keaktifan belajar siswa dengan menggunakan uji t. Hasil penelitian menunjukkan bahwa terdapat pengaruh penggunaan model pembelajaran two stay two stray terhadap peningkatan keaktifan belajar dan hasil belajar siswa pada mata pelajaran sosiologi.

Kata kunci: $\quad$ hasil belajar, keaktifan belajar, model pembelajaran two stay two stray
\end{abstract}

\section{PENDAHULUAN}

Sosiologi merupakan salah satu mata pelajaran yang diajarkan di tingkat sekolah menengah atas (SMA dan sederajat). Mata pelajaran Sosiologi dipandang oleh sejumlah siswa sebagai mata pelajaran yang membosankan sehingga siswa menjadi kurang aktif dalam proses belajar. Muatan materi sosiologi yang menyajikan banyak teori dan konsep seperti mengandung konsekuensi kepada siswa untuk menuntut semuanya dihafal secara baik. Model pembelajaran yang membosankan semakin membuat mata pelajaran ini kurang diminati oleh siswa. Strategi inovatif sudah dilakukan, namun pada prakteknya operasionalisasi model pembelajaran itu kurang efektif sehingga guru banyak yang kembali menggunakan model pembelajaran konvensional.

Mata pelajaran sosiologi diberikan juga pada siswa IPS di SMA Pasundan 3, dengan bobot tiga jam pelajaran setiap minggunya untuk kelas $X$. Dalam proses pembelajaran di kelas, guru mata pelajaran sosiologi di SMA Pasundan 3 Bandung telah mengupayakan untuk megajar dengan menggunakan berbagai variasi model pembelajaran, meskipun demikian hasilnya belum maksimal dikarenakan berbagai faktor baik itu dari segi penyampaian maupun kondisi siswa itu sendiri. Dari hasil observasi yang dilakukan oleh peneliti masalah yang terjadi dalam pembelajaran sosiologi adalah kurangnya keaktifan siswa dalam mengikuti proses pembelajaran di kelas dan juga hasil belajar yang masih dibawah kriteria ketuntasan minimal (KKM). Dari aspek keaktifan siswa dalam mengikuti proses pembelajaran masih banyak siswa yang berperan pasif, kurang responsif, dan tidak memperhatikan terhadap pembelajaran sehingga pada proses pembelajaran dari jumlah siswa kurang lebih 25 orang hanya sekitar 10 orang siswa yang aktif memperhatikan pembelajaran, dan hanya tiga sampai lima siswa yang aktif bertanya atau menjawab pertanyaan ketika pembelajaran berlangsung. Begitupun dari aspek hasil belajar dalam ranah kognitif masih ada siswa yang belum memahami apa yang telah disampaikan sehingga imbasnya masih banyak siswa yang melakukan remedial. Misalnya saja ketika diadakan ulangan harian dan ulangan tengah semester, hanya ada lima orang yang lulus dari jumlah siswa sekitar 25 orang. 
Selain itu, nilai yang diperoleh siswa pun masih rendah yaitu dibawah lima.

Model pembelajaran TSTS adalah pembelajaran yang memberikan kesempatan kepada kelompok untuk membagikan hasil dan informasi kepada kelompok lain. penggunaan model pembeajaran TSTS akan mengarahkan siswa untuk aktif, baik dalam berdiskusi, tanya jawab, mencari jawaban, menjelaskan dan juga menyimak materi yang dijelaskan oleh teman. Kelebihan dari model pembelajaran ini adalah lebih berorientasi pada keaktifan serta dapat membantu meningkatan minat dan prestasi belajar siswa.

\section{STUDI LITERATUR}

\subsection{Konsep Model Pembelajaran Two Stay Two Stray (TSTS)}

Salah satu model pembelajaran kooperatif adalah model TSTS. "Dua tinggal dua tamu" yang dikembangkan oleh Spencer Kagan 1992 dan biasa digunakan bersama dengan model Kepala Bernomor (Numbered Heads). Menurut Hidayat (2011, hlm. 132) "TSTS yaitu salah satu tipe pembelajaran kooperatif yang memberikan kesempatan kepada kelompok membagikan hasil dan informasi kepada kelompok lain. Hal ini dilakukan dengan cara saling mengunjungi atau bertemu antar kelompok untuk berbagai informasi". Dalam proses pembelajaran dengan menggunakan model TSTS, secara sadar ataupun tidak siswa akan melakukan kegiatan menyimak dan berbicara, dimana hal ini akan mendorong keaktifan siswa. Dengan menerapkan model TSTS siswa akan lebih banyak melakukan kegiatan menyimak secara langsung, dalam artian tidak selalu dengan cara menyimak apa yang pendidik utarakan yang akan membuat siswa merasa jenuh. Dengan penerapan model pembelajaran TSTS, siswa juga akan terlibat secara aktif, sehingga akan memunculkan semangat siswa dalam belajar.

Langkah - langkah Model Pembelajaran Two Stay Two Stray (TSTS)

Menurut Huda (2013, hlm. 140) menjelaskan prosedur pelaksanaan model TSTS sebagai berikut :

1. Siswa bekerja sama dengan kelompok berempat sebagaimana biasa

2. Pendidik memberikan tugas tugas pada setiap kelompok untuk didiskusikan dan dikerjakan bersama

3. Setelah selesai, dua anggota dari masing-masing kelompok diminta meninggalkan kelompoknya dan masing-masing bertamu ke dua anggota dari kelompok lain

4. Dua anggota yang tinggal dalam kelompok bertugas membagikan informas dan hasil kerja mereka ke tamu mereka

5. Tamu mohon diri dan kembali ke kelompok yang semula dan melaporkan apa yang mereka temukan dari kelompok lain

6. Setiap kelompok lalu membandingkan dan membahas hasil pekerjaan mereka semua

Langkah awal yang harus dilakukan dalam teknik ini adalah membagi siswa kedalam kelompok, masing-masing anggota kelompok berjumlah empat orang. Kemudian guru memberikan tugas yang sesuai dengan materi yang disampaikan untuk didiskusikan secara berkelompok. Dua anggota bertugas menjadi tuan rumah yang memberikan informasi kepada kelompok lain dan dua anggota lain bertugas menjadi tamu yang mencari informasi kepada kelompok lain. Kemudian setelah selesai anggota kelompok yang menjadi tamu kembali kepada kelompoknya yang semula untuk memberikan informasi yang telah mereka dapatkan dari kelompok lain.

Kelebihan dan Kekurangan Model Pembelajaran Two Stay Two Stray (TSTS)

Suatu model pembelajaran pasti memiliki kekurangan dan kelebihan. Adapun kelebihan dari model TSTS menurut Deliyana (dalam Kurniati, 2012, hlm. 26) adalah sebagai berikut:

1. Dapat diterapkan pada semua kelas/tingkatan

2. Kecenderungan belajar siswa menjadi lebih bermakna

3. Lebih berorientasi pada keaktifan.

4. Peserta didik akan lebih berani mengemukakan pendapatnya

5. Menambah kekompakkan dan rasa percaya diri siswa

6. Kemampuan berbicara siswa dapat ditingkatkan

7. Membantu meningkatkan minat dan prestasi belajar siswa

Sedangkan kekurangan dari model TSTS adalah:

1. Waktu yang dibutuhkan lebih lama

2. Kecenderungan hanya peserta didik yang memiliki kemampuan tinggi yang aktif

3. Butuh persiapan materi dan tenaga

4. Suasana kelas cenderung gaduh

Berdasarkan pemaparan tersebut, bahwa kelebihan model pembelajaran TSTS adalah lebih fleksibel untuk diterapkan karena bisa diterapkan pada semua tingkatan dan berbagai mata pelajaran termasuk mata pelajaran sosiologi. Proses belajar pun akan menjadi lebih bermakna karena siswa mencoba untuk menggali lebih dalam mengenai 
materi yang sedang dipelajari. Model pembelajaran TSTS juga lebih berorientasi pada keaktifan karena siswa lah yang harus aktif menjadi sumber pembelajaran, baik dari kelompoknya sendiri ataupun saat berkunjung pada kelompok lain. Selain itu, kelebihan model TSTS juga dapat membuat siswa menjadi lebih berani, percaya diri, dan kompak dalam mengerjakan tugas kelompok. Model pembelajaran TSTS juga dapat membantu untuk meningkatkan kemampuan berbicara siswa dan meningkatkan minat dan prestasi belajar siswa. Sedangkan kekurangan dari model TSTS adalah waktu yang dibutuhkan dalam proses pemelajaran relatif lama, dan seringkali yang lebih aktif dalam pembelajaran adalah siswa yang mempunyai kemampuan tinggi. Model pembelajaran TSTS juga mempunyai persiapan yang cukup berarti dalam hal materi dan tenaga. Suasana kelas juga menjadi cenderung lebih gaduh apabila menggunakan model TSTS.

\subsection{Konsep Hasil Belajar}

Hasil belajar merupakan tolak ukur yang digunakan untuk menentukan tingkat keberhasilan siswa dalam mengetahui dan memahami suatu mata pelajaran, biasanya dinyatakan dengan nilai yang berupa huruf atau angka-angka. Hasil belajar dapat berupa keterampilan, nilai dan sikap setelah siswa mengalami proses belajar. Menurut Sudjana (2014, hlm. 22) "Hasil belajar adalah kemampuan kemampuan yang dimiliki siswa setelah ia menerima pengalaman belajarnya, dalam pengertian yang lebih luas mencangkup bidang kognitif, afektif, dan psikomotorik".

\subsection{Konsep Keaktifan Belajar}

Secara harfiah keaktifan berasal dari kata aktif yang berarti sibuk, giat. Aktif mendapat awalan kedan -an, sehingga menjadi keaktifan yang mempunyai arti kegiatan atau kesibukan. Anggraeni (2014, hlm. 6) mengemukakan bahwa "keaktifan belajar adalah kegiatan atau kesibukan siswa dalam kegiatan belajar mengajar di sekolah maupun di luar sekolah yang menunjang keberhasilan belajar siswa." Berdasarkan pendapat tersebut segala keaktifan siswa pada proses belajar sangat menentukan keberhasilan pencapaian dari tujuan pembelajaran tersebut. Tingkat keaktifan belajar murid dalam suatu proses pembelajaran juga sebagai tolak ukur dari kualitas pembelajaran tersebut.

\section{METODE PENELITIAN}

Metode yang digunakan dalam penelitian ini adalah kuasi eksperimen, menurut Sugiyono, (2011, hlm. 109) metode kuasi eksperimen "sebagai metode penelitian yang digunakan untuk mencari pengaruh perlakuan tertentu terhadap yang lain dalam kondisi yang terkendalikan". Penelitian ini menggunakan desain nonequivalent control group design. Dalam penelitian ini yang menjadi populasi adalah seluruh siswa SMA Pasundan 3 Bandung kelas X IPS, XI IPS, dan XII IPS tahun ajaran 2016/2017 karena kelas tersebut mempelajari mata pelajaran Sosiologi sesuai dengan bidang keahlian yang ditekuni oleh peneliti. Dalam penelitian ini, penelitian menggunakan teknik purposive sampling yaitu, menentukan sendiri sampel yang akan dignakan karena beberapa pertimbangan tertentu yang disesuaikan dengan kebutuhan peneliti pada penelitian yang akan dilaksanakan. Sehingga dalam penelitian ini sampel yang digunakan ini adalah tiga kelas, yaitu kelas X IPS I, X IPS II, dan kelas X IPS III SMA Pasundan 3 Bandung tahun ajaran 2016/2017. Instrumen penelitian yang digunakan adalah tes kemampuan yang terdiri dari pretest dan postest, lembar observasi keaktifan siswa, dan dokumentasi. Teknik analisis data yang digunakan adalah uji normalitas, uji homogenitas, dan uji hipotesis dengan menggunakan uji t. Uji t yang digunakan adalah paired sample $t$ test.

\section{HASIL DAN PEMBAHASAN}

Penelitian ini dilakukan dengan dua kali pertemuan kegiatan pembelajaran dan dua kali tes setiap kelasnya. Kegiatan awal pada penelitian ini adalah memberikan pretest pada masing - masing kelas. Data hasil pretest ini dijadikan sebagai pedoman awal peneliti untuk mengetahui kondisi awal pengetahuan atau tingkat kemampuan siswa pada materi yang akan disampaikan, dimana materi yang akan dipelajari adalah materi pengendalian sosial. Hasil rata-rata nilai hasil belajar kelas dengan model pembelajaran two stay two stray memiliki rata-rata pretest sebesar 45,30 dengan kategori kurang, setelah diberikan perlakuan mendapatkan hasil rata-rata posttest sebesar 62,75 yang termasuk pada kategori cukup. Demikian pula pada kelas kontrol yang menggunakan model ceramah mengalami peningkatan dari rata-rata hasil pretest sebesar 51,43 dengan kategori kurang menjadi 62,30 yang termasuk pada kategori cukup. Dalam penelitian ini observasi keaktifan belajar siswa 
dilakukan dua kali, yaitu dilakukan sebelum treatment dan sesudah treatment. Hal ini dimaksudkan untuk mengetahui terlebih dahulu kondisi awal keaktifan belajar siswa sebelum diberikan perlakuan yang selanjutnya dapat dijadikan sebagai pembanding hasil keaktifan belajar siswa setelah diberikan perlakuan. Adapun hasil rata-rata keaktifan belajar siswa sebesar 55,70 termasuk pada kategori cukup aktif Setelah diberikan perlakuan berupa penerapan model pembelajaran two stay two stray nilai keaktifan belajar menjadi sebesar 67,45 yang termasuk kategori baik. Tahapan analisis data yang dilakukan adalah uji normalitas dimana data yang diperoleh berdistribusi normal, uji homogenitas, dan uji hipotesis. Hasil uji hipotesis yang dilakukan adalah sebagai berikut :

Diperoleh nilai thitung adalah $-6,478$ sedangkan ttabel adalah -2,093. Maka, hasil yang diperoleh adalah -thitung <-ttabel. Berdasarkan ketentuan dari hipotesis yang telah dibuat maka dapat diketahui bahwa H0 ditolak dan $\mathrm{H} 1$ diterima, sehingga dapat disimpulkan bahwa terdapat pengaruh penerapan model pembelajaran Two Stay Two Stray (TSTS) dalam meningkatkan hasil belajar sosiologi pada siswa IPS di SMA Pasundan 3 Bandung.

Diperoleh nilai thitung adalah $-13,014$ sedangkan ttabel adalah -2,093. Maka, hasil yang diperoleh adalah -thitung < -ttabel. Berdasarkan ketentuan dari hipotesis yang telah dibuat maka dapat diketahui bahwa $\mathrm{H0}$ ditolak dan H1 diterima, sehingga dapat disimpulkan bahwa terdapat pengaruh penerapan model pembelajaran Two Stay Two Stray (TSTS) dalam meningkatkan keaktifan belajar sosiologi pada siswa IPS di SMA Pasundan 3 Bandung.

Penggunaan model pembelajaran two stay two stray diterapkan pada kelas X IPS 3 sebagai kelas eksperimen 2 dengan jumlah siswa sebanyak 20 orang. Dalam pelaksanaannya terdapat tahap-tahap dalam pembelajaran dengan menggunakan model two stay two stray yaitu, tahap persiapan, presentasi guru, kegiatan kelompok, formalisasi, dan evaluasi.

Pada tahapan pertama pembelajaran peneliti memberikan pretest kepada siswa dengan jumlah soal 30 pilihan ganda. Materi yang diujikan adalah materi pengendalian sosial. Jumlah siswa yang mengikuti pretest adalah 19 orang. Waktu pengerjaan soal berlangsung selama 45 menit. Pemberian pretest ini ini bertujuan untuk mengetahui kemampuan awal siswa dalam pemahaman materi pengendalian sosial. Pada saat proses pelaksanaan pretest berlangsung cukup kondusif meskipun masih ada beberapa siswa yang berisik. Semua siswa dapat menyelesaikan soal sesuai dengan waktu yang telah ditentukan. Pada tahapan ini juga peneliti memberikan gambaran umum tentang proses pembelajaran yang akan berlangsung. Dalam hal ini peneliti menjelaskan teknis jalannya pembelajaran TSTS agar kegiatan dapat berlangsung dengan baik dan tertib. Setelah pemberian pretest selesai peneliti mulai melakukan perlakuan bagi siswa yaitu melaksanakan kegiatan pembelajaran dengan menggunakan model pembelajaran TSTS pada materi ajar pengendalian sosial. Pada tahapan pertama ini peneliti menyajikan pemaparan inti dari materi pengendalian sosial, hal ini bertujuan agar siswa terlebih dahulu memahami materi yang akan dipelajari.

Setelah pemaparan materi selesai maka dilanjutkan dengan tahapan kedua yaitu diskusi kelompok. Peneliti memberikan pembahasan yang berbeda pada masing-masing kelompok berkaitan dengan materi pengendalian sosial. Peneliti memperhatian dan membimbing proses jalannya diskusi, dimana terlihat siswa cukup antusias dalam mengerjakan tugas yang diberikan serta bekerja sama dalam mengerjakan tugas tersebut.

Tahapan ketiga adalah setelah diskusi di kelompok awal selesai, dua anggota dari masingmasing kelompok diminta meninggalkan kelompoknya dan masing-masing bertamu ke dua anggota dari kelompok lain. Tugas dua orang anggota yang bertamu adalah memahami dan mencatat pembahasan dari kelompok lain, sedang dua orang yang tinggal bertugas untuk menjelaskan materi pembahasan kepada tamu yang datang. Pada kegiatan ini awalnya siswa tampak bingung untuk melakukan kegiatan pembelajaran, namun dengan bimbingan peneliti proses diskusi dapat berlangsung dengan cukup kondusif.

Tahapan keempat adalah tamu mohon diri dan kembali ke kelompok yang semula dan melaporkan apa yang mereka temukan dari kelompok lain. Setiap kelompok lalu membandingkan dan membahas hasil pekerjaan mereka semua. Setelah kelompok selesai membahas materi hasil temuan dari kelompok lain, dilanjutkan dengan presentasi masing-masing kelompok.

Tahapan terakhir adalah dilakukan evaluasi dimana siswa diberikan kesempatan untuk memberikan komentar dan evaluasi mengenai jalannya proses pembelajaran yang telah dilaksanakan. Siswa juga diminta memberikan kesimpulan mengenai materi yang telah dipelajari.

Perbandingan hasil pretest dan posttest pada kelas eksperimen 2 yang menggunakan model pembelajaran two stay two stray menunjukkan ratarata nilai pretest sebesar 45,30 dan rata-rata nilai posttest adalah sebesar 62,75. Jika dipersentasikan maka peningkatan nilai rata-rata hasil belajar siswa adalah $38,52 \%$. Sementara hasil keaktifan belajar menunjukkan rata-rata skor sebelum diberikan perlakuan sebesar 55,70 dan rata-rata skor setelah 
diberikan perlakuan sebesar 67,45. Jika dipresentasikan maka peningkatan skor rata-rata hasil observasi keaktifan belajar siswa adalah $21,09 \%$.

Siswa dapat mengikuti pembelajaran dengan lebih aktif, terlihat siswa cenderung lebih banyak bertanya, mengemukakan pendapat, mendengarkan pemaparan materi pembelajaran dan mencatat halhal penting selama pembelajaran. Siswa juga menjadi aktif dalam mendengarkan percakapan atau diskusi kelompok, mendengarkan presentasi hasil tugas siswa lainnya. mengemukakan pendapat saat diskusi kelas berlangsung dan melakukan interupsi jika mengetahui terdapat kesalahan konsep materi pada penjelasan guru ataupun siswa. Selain itu siswa juga mempunyai minat belajar yang lebih tinggi.

Berdasarkan pengujian hipotesis menggunakan uji $\mathrm{t}$ diperoleh data yang menunjukkan bahwa terdapat pengaruh penggunaan model pembelajaran two stay two stray dalam meningkatkan hasil belajar maupun kekatifan belajar siswa di kelas. Ini menunjukkan bahwa model pembelajaran two stay two stray dapat meningkatkan hasil belajar dan keaktifan belajar siswa pada mata pelajaran sosiologi lebih baik dari model pembelajaran konvensional metode ceramah. Hal ini sejalan dengan yang dikemukakan oleh Deliyana (dalam Kurniati, 2012, hlm. 26) bahwa kelebihan dari model TSTS adalah pembelajaran yang lebih berorientasi pada keaktifan, dan dapat membantu meningkatkan minat dan prestasi belajar siswa.

\section{KESIMPULAN}

Terdapat pengaruh penggunaan model pembelajaran two stay two stray dalam meningkatkan hasil belajar mata pelajaran sosiologi pada kelas eksperimen 2, dengan persentasi rata-rata kenaikan sebesar 38,52\%.

Terdapat pengaruh penggunaan model pembelajaran two stay two stray dalam meningkatkan keaktifan belajar siswa pada mata pelajaran sosiologi pada kelas eksperimen 2, dengan persentasi rata-rata kenaikan sebesar $21,09 \%$.

\section{REFERENSI}

Anggraeni, S. (2014). Penerapan model pembelajaran kooperatif tipe tgt (teams games tournament) untuk meningkatkan keaktifan dan prestasi belajar sosiologi pada siswa kelas $\mathrm{x}$ iis 4 sma batik 1 surakarta tahun pelajaran 2014/2015.
SOSIALITAS : Jurnal Ilmiah Pend. Sos Ant, 7 (1), hlm. 6

Hidayat. (2011). Model - model Pembelajaran Berbasis PAIKEM. Bandung: CV. Siliwangi \& CO.

Huda, Miftahul. (2013). Cooperative Learning. Yogyakarta. Pustaka Pelajar.

Kurniati, Rini. (2012). Pengaruh model pembelajaran cooperative learning teknik two stay two stray (dua tinggal dua bertamu) terhadap hasil belajar siswa pada mata pelajaran ekonomi. Skripsi Program Studi Ekonomi. Tidak diterbitkan

Sudjana, Nana. (2014). Penilaian Hasil Proses Belajar Mengajar. Bandung: Remaja Rosdakarya.

Sugiyono. (2011). Metode Penelitian Kombinasi (Mixed Methods). Bandung: CV. Alfabeta 